\title{
Inferential Patterns of Emotive Meaning
}

\author{
Fabrizio Macagno and Maria Grazia Rossi
}

\section{Introduction}

[...] people often do not consider the entire meaning of words. That is, words often signify more than they appear to, and when people try to explain their meaning, they do not represent the entire impression made in the mind. This is so because for an uttered or written sound to signify is nothing other than to prompt an idea connected to this sound in the mind by striking our ears or eyes. Now, frequently, in addition to the main idea which is considered its proper meaning, a word may prompt several other ideas - which may be called incidental ideas - without our realizing it, although the mind receives their impressions. For example, if we say to someone, "You lied about it," and we consider only the principal meaning of this expression, this is the same as saying: "You know that the contrary of what you say is true." But in common use these words carry an additional idea of contempt and outrage. They make us think that the person who says them does not care whether they injure us, and this makes the words insulting and offensive. (Arnauld \& Nicole, Logic, I, 14).

This passage from the Logic of Port Royal addresses a very actual philosophical problem, which has crucial implications not only on how language is conceived, but also more importantly on how language is used and modified strategically.

This ancient account of "incidental ideas" and the related issues of derogatory words and redefinitions become strikingly modern when we look at the 2016 Presidential elections. By rejecting the "politically correct" image of a presidential candidate, Trump adopted a type of rhetoric characterized by the frequent use of

\footnotetext{
F. Macagno $(\varangle) \cdot$ M. G. Rossi

Instituto de Filosofia da Nova (IFILNOVA), Facultade de Ciências Sociais e Humanas, Universidade Nova de Lisboa, Lisbon, Portugal
}

(C) The Editor(s) (if applicable) and The Author(s), under exclusive license to 
what has been reported by the press as "charged expressions" or "loaded language,"1 which in the philosophical literature have been commonly referred to as "ethical" or emotive words (Stevenson, 1937, 1944). Words such as "losers, ${ }^{2,}$ "bimbo, "," "stupid," "scum," "fools" are only the most stereotypical examples of terms that are not simply used to describe reality by modifying the cognitive response of the interlocutor (i.e., "informing" him), but more importantly to affect the interlocutor's attitudes towards a state of affairs and suggest a course of action. Ethical (or emotive) words are a powerful rhetorical instrument used for "framing" an issue (Druckman, 2002; Entman, 1993; Sniderman \& Theriault, 2004) and influencing the interlocutors' decisions. However, their nature and their effects constitute also crucial philosophical problems, involving philosophical positions, such as nominalism (Richard, 2008), contextualism, externalism, or inferentialism (Hom, 2010), some of which have been debated over centuries. Such issues are recently attracting increasing attention from both a philosophical and linguistic perspective, even though most of the studies have focused on a specific type of ethical words, slurs (Blakemore, 2015; Croom, 2011, 2014; Hom, 2008, 2010; Richard, 2008).

This paper investigates a specific dimension of loaded language, namely the defeasibility (or rather cancellability) of the expressive force it triggers. Many studies have advanced various theories, often conflicting with each other, on how the expressive force is or can be originated - whether externally through social conventions (Anderson \& Lepore, 2013), semantically from semantic content (Hom, 2008, 2010) or presupposition triggers (Schlenker, 2007, p. 137), or inferentially as part of the broader meaning (rules of use) of a word (Whiting, 2013; Williamson, 2009). Such works, however, tend to dismiss the other dimension of the semantic/pragmatic interface, namely how such an expressive force is triggered, developed, cancelled, or modified in different contexts. Our goal is to focus on the cancellable nature of the "expressive force" of emotive words (Capone, 2014, pp. 303-304) and investigate it as a defeasible inference used for performing presumptively a specific speech act.

\footnotetext{
${ }^{1}$ See for instance: Eli Stokols (2016). Trump's loaded words fuel campaign freefall. Politico, 8 September 16. Retrieved from: http://www.politico.com/story/2016/08/donald-trump-campaignstatements-226840 (accessed on 01 September 2020); John Wildermuth (2016). Trump's loaded language a reminder of words' power. San Francisco Chronicle, 9 August 2016. Retrieved from: http://www.sfchronicle.com/politics/article/Trump-s-loaded-language-a-reminder-ofwords-9133067.php (accessed on 01 September 2020); A Surprising Thing Happens When Presidential Candidates Use Emotional Language. The Huffington Post, 21 March 2016. Retrieved from: http://www.huffingtonpost.com/entry/donald-trump-emotional-inflammatory-language_ us_56e84b60e4b0860f99da8d3e?utm_hp_ref=science (accessed on 01 September 2020).

${ }^{2}$ Trump Lashes Out At McCain: 'I Like People Who Weren't Captured'. NPR, 8 July 2015. Retrieved from: http://www.npr.org/sections/thetwo-way/2015/07/18/424169549/trump-lashesout-at-mccain-i-like-people-who-werent-captured (accessed on 01 September 2020).

${ }^{3}$ Donald Trump retweets Megyn Kelly 'bimbo' jab as women react to insults. The Guardian, 7 August 2015. Retrieved from: https://www.theguardian.com/us-news/2015/aug/07/donald-trumpmegyn-kelly-bimbo-women-republican-debate (accessed on 01 September 2020).
} 


\section{Characteristics of Emotive Meaning}

The notion of "incidental ideas" mentioned in the aforementioned excerpt from Port Royal Logic is a vague metaphor for a dimension of meaning that has been investigated in the recent years under the label of "expressive meaning" (Croom, 2014; Hedger, 2012, p. 76), "expressive force," or "derogatory content" or "derogatory properties" of slurs and pejoratives (Hom, 2008, 2010), and was analyzed in the emotivistic tradition as "emotive meaning" (Stevenson, 1937). In order to address the relationship between ethical terms (and slurs in particular) and emotive meaning, it is useful to focus on the defeasible nature of the latter, its complex structure, and how it can be represented.

\section{The Defeasibility of Emotive Meaning}

In the literature, the essential characteristic of slurs and emotive words in general has been acknowledged to be their expressive force (Croom, 2014, p. 230; Hom, 2008, 2010, p. 168), namely their potential to express the speaker's (negative) psychological attitudes towards the state of affairs referred to (the target) (see also Bianchi, 2014b). This "force" is in itself a complex notion, as it is a characteristic of specific words that explains a stable use of the utterances in which they occur. The most important features of expressive force can be summarized as follows (Hom, 2010, pp. 164-170):

1. Force variability. The derogatory force of distinct pejoratives varies in strength, type and intensity of the emotion expressed.

2. Historical variability. The force of pejorative terms varies over time, and is sensitive to the relevant social facts.

3. Content-dichotomy puzzle. Pejoratives can be used in an orthodox and nonorthodox way. Orthodox occurrences are characterized by the following properties, which are contrary to the non-orthodox ones:

(a) Non-displaceable. They appear to derogate even when embedded in different contexts such as in the antecedent of a conditional, under negation, inside of a question, in an attitude report, etc.

(b) Agent centered. They appear to be inseparable from the attitudes of their speaker.

(c) No-truth conditional contribution. Slurring uses of derogatory words do not have truth-conditional content, whereas non-slurring uses do have truthconditional content.

These three aspects define various dimension of cancellability (defeasibility) of the expressive force. The expressive force varies according not only to the different emotive words, but also to the broader conversational setting, defined in terms of the culture of the members of a speech community (Kecskes, 2013, 
p. 141), and the presumable intention of the speaker (orthodox vs. non-orthodox uses). In particular, the historical variability captures the strict interdependence between emotive words and the culture of the relevant speech community, which can vary in time depending on the shared evaluations of the states of affairs or entities referred to (Capone, 2016, p. 177). Moreover, the expressive force is absent when emotive words (and in particular pejoratives) are used for specific non-derogatory purposes, which include appropriated uses (the use of slurs by the targeted members or groups for non-derogatory purposes) (Bianchi, 2014a) and "meta-linguistic" uses, namely when the speaker is using such epithets for "objecting to discriminatory discourse," reporting the racist contents carried by epithets (Bianchi, 2014b, p. 477).

Such characteristics seem to indicate that (in at least several cases, which we will illustrate below) the "expressive force" can be regarded as a type of intended and automatic inference, which is drawn in lack of contrary evidence and until contrary evidence is provided (Capone, 2011; Jaszczolt, 2005, p. 46). Unless the speaker expresses his or her strong intention by providing specific clues, the inference usually triggered by emotive words is hardly cancellable (Capone, 2013). Considering the usual association between the concept of conversational implicature and the conscious processing of a contextual inference (Carston, 2002, 2004; Sperber \& Wilson, 2002), we will focus only the logical dimension of such inferences, which we will refer to as "intended inferences" to avoid terminological confusions. In the next sections, the problem of their automaticity (Capone, 2010) will be discussed.

\section{The Twofold Nature of Expressive Force}

As mentioned above, the notion of expressive force is complex, as it is in itself defined by referring to the (prototypical) uses of emotive words, namely to express an evaluation of their targets (to display an attitude) (Hom, 2010, p. 171), thus conveying an emotion towards it (Capone, 2014). In case of pejoratives, this evaluation is negative, and is presumptively used for insulting, degrading, or performing other derogatory acts (Bianchi, 2014b; Capone, 2016).

This twofold nature was clearly captured by Stevenson's emotivistic approach. In his works on ethical utterances, Stevenson (Stevenson, 1937, 1938a, 1938b, 1944) developed an account of ethical words based on a causal account of meaning (Dancy, 2013, p. 736). On this view, the meaning of a term was understood as an unchanged dispositional property (Stevenson, 1944, p. 46), a tendency to produce certain responses that is the result of the habits of the speakers. According to Stevenson, words can be used for two distinct and often interrelated purposes (Richard, 2012, p. 443): descriptively, to "record, clarify, and communicate beliefs," or dynamically, to "give vent to feelings, create moods, or to incite people to actions or attitudes" (Stevenson, 1937, p. 21). These two tendencies are referred to as "descriptive" and "emotive" meaning. 
Stevenson noticed how some words (including slurs and ethical terms such as "peace," "democracy," or "terrorism") are connected with (or prototypically used to produce) emotions, or rather action-oriented, immediate responses. Some of them consist in venting emotions, others in expressing an attitude that can affect the interlocutor's evaluation of the represented state of affairs. As Stevenson (Stevenson, 1937, pp. 18-19), put it “instead of merely describing people's interests, they change and intensify them. They recommend an interest in an object, rather than state that the interest already exists," as they have the tendency to lead the hearer towards a decision by affecting his or her system of interests (Stevenson, 1938a, 1938b, 1944, p. 54). Words characterized by an emotive meaning can be used for persuading the interlocutor or the audience to carry out a specific action.

On Stevenson's view, ethical or emotive terms are characterized by the combination of their descriptive and emotive meaning (Stevenson, 1944, p. 206; 210). Since their potentiality consists in expressing an attitude towards a state of affairs, which can direct or affect the interlocutor's interests towards it, they provide at the same time a representation and an evaluation, which is presupposed by the emotion expressed. For this reason, the speaker can manipulate or redirect the interlocutor's attitude (i.e. evaluation or interests) towards a state of affairs (in cognitive approaches to emotions, a "target," see De Sousa, 1987, p. 20) by redefining the "descriptive meaning" or the "emotive meaning" of the ethical word used to refer to it (Stevenson, 1938 b, p. 332). In the first case, the ethical term is "persuasively defined," in the second case, it is "quasi-defined."

The complex structure of emotive words, characterized by a "tendency" to be used for affecting the interlocutors' attitudes towards a state of affairs and the inherently defeasible nature of the emotive meaning leads to the problem of representing their "expressive force." In the next sections, an inferentialist account of emotive words will be presented, in which the "tendency" or "potential" characterizing emotive words and the prototypical dynamic (or, in case of pejoratives, derogatory) uses will be explained as forms of argument. More specifically, the implicitly conveyed meaning will be investigated and represented through argumentation schemes or argument patterns, namely the informal reasoning that can be used to account for a specific intended inference (Leech, 1983, p. 30). This approach will be shown to explain the complex nature of the emotive meaning.

\section{Emotive Meaning as Defeasible Inferences}

Stevenson's approach to emotive meaning has the clear advantage to account for the defeasible nature of the expressive force and the prototypical association between the uses of emotive words and specific speech acts (Stevenson, 1944, p. 210). However, by investigating emotive meaning in terms of the acts presumptively performed by using emotive words, emotivism fails to explain two crucial aspects thereof, namely 1) the inferences from descriptive uses to dynamic ones (and vice versa) (Geach, 1965, p. 463), and 2) the inferences from unasserted occurrences of 
ethical terms (Hom, 2010, p. 171). More precisely, Stevenson's theory cannot explain the dynamic use of the following conclusion:

If doing a thing is bad, getting your little brother to do it is bad.

Tormenting the cat is bad.

Ergo, getting your little brother to torment the cat is bad.

Supposing that the major premise is asserted by the father to his older son, the father's condemnation of the son's behavior (dynamic use of "bad") cannot be inferred from an assertion (descriptive use of "bad"). Similarly, the embedding of an emotive term under negation or in a question ("are they scum?") triggers inferences that are not related to the dynamic purpose of affecting the interlocutor's attitudes. Finally, the distinction between the two types of "potentialities" of a word can explain why the emotive meaning can vary in time (habits change) but not how it can be modified on purpose. In order to address these shortcomings, an inferentialist approach will be proposed, in which the relationship between emotive words and slurring effects are mediated by evaluative inferences.

\section{An Argumentative Account of Ethical Words}

The "descriptive" and "emotive" meaning of ethical words, i.e. the tendency to elicit cognitive or emotive responses, can be interpreted from a logical ${ }^{4}$ perspective as different types of intended and defeasible inferences guided by different types of presumptions guiding the inferential process. Such inferences are normally described as conversational implicatures, and analyzed according to the set of presumptions codified by Grice in his maxims. However, the mechanism underlying the reconstruction of an intended inference can be represented using more specific inferential patterns, and relying on specific presumptions that can be ordered in levels of acceptability. As Grice underscored (Grice, 1975, p. 50), together with the conversational maxims, presumptions of different type are involved in reconstructing an implicature, such as the conventional meaning of the words used, contextual information, background knowledge, and the shared knowledge.

These different types of information can be represented through different levels of presumptions, leading to default (and thus defeasible) conclusions that can be stronger or weaker depending on the weight of the presumption within a specific context and the available evidence rebutting it (Atlas \& Levinson, 1981; Bach \& Harnish, 1979, Chap. 1; Dascal \& Wróblewski, 1988; Macagno, 2012a; Patterson, 2005). The levels of presumptions can be represented in Fig. 1 below (Macagno, 2017, p. 287).

\footnotetext{
${ }^{4}$ The term "logical" shall be considered as referring to the natural language logic investigated in the dialectical tradition and in argumentation theory.
} 


\section{Levels of presumptions}

\begin{tabular}{|c|c|}
\hline 0. Pragmatic & $\begin{array}{l}\text { Use-Act; Type of dialogue-type of move } \\
\text { (ex. Assertive sentences are usually used to inform the } \\
\text { hearer; In eristic dialogues interlocutors are expected } \\
\text { to vent emotions). }\end{array}$ \\
\hline 1. Linguistic & $\begin{array}{c}\text { Definitions, syntactic structures } \\
\text { (ex. 'Man' is usually used to mean a 'rational } \\
\text { animal'). }\end{array}$ \\
\hline 2. Factual, encyclopedic & $\begin{array}{c}\text { Facts, events, stereotypes } \\
\text { (ex. People usually know that France is not a } \\
\text { monarchy now). }\end{array}$ \\
\hline 3. Values, interests & $\begin{array}{l}\text { The interlocutor's interests/values... } \\
\text { (ex. Professor } x \text { is usually very critical and writes no } \\
\text { recommendation letters; } x \text { is usually against the } \\
\text { freedom of press...). }\end{array}$ \\
\hline
\end{tabular}

Fig. 1 Levels of presumptions

These presumptions can be classified according to their content and ordered and assessed based on their defeasibility conditions (Clark, 1996, Chap. 4; Clark \& Brennan, 1991). Presumptions closer to the conversational situation in which the utterance is performed (namely more related to the interlocutors' specific goals and knowledge) are likely to be less subject to default than more generic presumptions. Thus, specific presumptions resulting from direct evidence concerning the interlocutor's behavior (specific conversational goals, values, interests, behavior of the interlocutor) are less likely to be subject to default than generic pragmatic (based on form-purpose presumptions), encyclopedic or linguistic information, as less abstract from the specific setting in which the utterance is made.

These presumptions can constitute the premises of more specific inferential patterns (Macagno, 2012a; Macagno \& Walton, 2013), represented using patterns that are more specific than formal rules of inference - called loci or topoi in the dialectical tradition (Macagno, Walton, \& Tindale, 2014) - and described as argumentation schemes (Walton, Reed, \& Macagno, 2008). In case of emotive words, the descriptive meaning can be regarded as an inference or a set of inferences attributing a predicate to an entity (a subject) based on specific characteristics and definitional premises (the process of "naming" reality). The emotive meaning can be interpreted as an inference (or as set of inferences) leading from a description of a state of affairs to a value judgment thereon (evaluation), and in some cases to a further inference to the proposal of a commitment to course of action (decision-making inferences) (Leech, 1983, p. 30). 
The inferences that can be drawn from the use of an ethical term are thus constrained by a limited number of inferential patterns, leading to a limited number of conclusions. In the following subsection, we will show in detail the inferential structure of the complex inferences drawn from emotive words.

\section{Inferences and Descriptive Meaning}

Based on the presumptive structure described above, the descriptive meaning can be represented as an inferential passage aimed at classifying a state of affairs. This inference is grounded on classificatory premises, which can be very different in kind. A classification (the attribution of a property to a subject/entity based on some properties characterizing it) can be grounded on definitions, descriptions, or stereotypes that are presumed for distinct reasons to be shared by the interlocutors. While definitional characteristics can be presumed to be hardly defeasible (stronger contextual evidence is needed to defeat them), elements of collocative meaning (such as "non-criterial properties that we have learnt to expect a referent to possess," including physical, social, typical properties within specific contexts, see Leech, 1981 , p. 12) lead to more defeasible conclusions. In both cases, the inference can be represented using the following scheme from classification (Walton et al., 2008, p. 319).

\section{Argumentation scheme 1: Argument from classification}

\begin{tabular}{l|l}
\hline PREMISE 1 & $\begin{array}{l}\text { If some particular thing } a \text { can be classified as falling under verbal category } C \text {, then } \\
a \text { has property } P \text { (in virtue of such a classification). }\end{array}$ \\
\hline Premise 2 & $a$ can be classified as falling under verbal category $C$. \\
\hline Conclusion & $a$ has property $P$. \\
\hline
\end{tabular}

The reasonable and correct application of this scheme can be assessed dialogically by taking into account its defeasibility conditions, represented by the following critical questions:

CQ1: What evidence is there that a definitely has property $\mathrm{C}$, as opposed to evidence indicating room for doubt about whether it should be so classified?

CQ2: Is the classification premise the definition of $P$ ? Or is it merely a description thereof? Or is it a stereotype reporting only on a shared and unproven relationship between the two properties?

This scheme underlies both the use of an ethical word and the possible inferences that can be drawn from it (Macagno \& Walton, 2014, Chap. 3). In particular, the use of an emotive word (or slur) can be justified based on its definition or generally accepted description. An individual can be named as "politically correct" because his or her "avoiding language and practices which could offend political sensibili- 
ties." A group of people can be labeled metaphorically as "scum" based on alleged low actions.

The classification scheme is one of the grounds of evaluative inferences, namely reasoning steps leading to a specific type of predication, consisting in the attribution of an evaluative predicate (the species of good and evil, see Aristotle, Topics, 123b9) based on specific presumptions (Aristotle, Topics, 116a13-116a21), such as "which is more lasting or secure is more desirable than that which is less so." These types of evaluative premises are culture-dependent reasons for classifying something as desirable or not (Perelman \& Olbrechts-Tyteca, 1951), and - just like other types of classifications - can be grounded on the definitions of evaluative predicates (what is good, desirable, dangerous, etc. see Vendler, 1963; von Wright, 1963c) or stereotypes, and thus be more or less defeasible. For example, "politically correct" can be judged as desirable and good as it is the privation of something evil (offending, which provokes pain). Similarly, "scum" is generally evaluated negatively, as it is commonly described as something ill or worthless.

Emotive words rely on prototypical associations between a classification and an evaluation, which lead defaultively to a conclusion that is not based on reasons different from the act of labeling the entity. This type of short-circuited inference skips the justification of the evaluation, which otherwise would have to take into account factors such as the relationship between actions and habits, or the link between consequences (actions) and values. For example, a typical evaluative pattern can be the following argument from consequences to evaluation (adapted from Walton et al., 2008, p. 332).

\section{Argumentation scheme 2: Argument from consequences to evaluation.}

\begin{tabular}{l|l}
\hline PREMISE 1 & If agent $A$ brings about (doesn't bring about) $B$, then $C$ will occur. \\
\hline $\begin{array}{l}\text { Consequence } \\
\text { premise }\end{array}$ & $C$ is a good (bad) outcome (from the point of view of $A$ 's goals). \\
$\begin{array}{l}\text { Evaluation } \\
\text { premise }\end{array}$ & $\begin{array}{l}\text { That whose production is good is itself also good, and vice versa; that whose } \\
\text { destruction is bad is itself also good, and vice versa (Boethius, De Topicis } \\
\text { Differentiis, 1190A 7-1190B 1). }\end{array}$ \\
\hline Conclusion & Therefore, $B$ and $A$ are good (bad). \\
\hline
\end{tabular}

This scheme presupposes an evaluation of the consequences of actions, and the judgment on the formal or effective cause of the consequence (the action or the agent) is limited to the circumstance (not generalizable to similar actions or to all agent's actions). Emotive words skip this inferential evaluative mechanism by providing a simpler, less critical evaluation based on stereotypies or commonly accepted and presumptive premises (Walton, 1995). In the extreme case of slurs, the evaluative properties can be explained as part of the properties used for describing the term itself, either as definitional characteristics (such as "bimbo," distinguished by the feature of "being foolish") or properties typically and culturally associated with the aspect of the referents considered (such as in case of racial epithets). 


\section{The Dynamic Uses of Ethical Words}

Value judgments can be the premises of further action-oriented inferences, which can account for the "dynamic uses" of ethical words, namely "inciting people to action" or venting emotions (Stevenson, 1937, pp. 21-22). In both cases, the dynamic uses are aimed at altering people's attitude (affection), either by encouraging the hearer to commit himself to a course of action or behavior, or arousing sympathy (Ben-Ze'ev, 2000, Chap. 11). In particular, the action-oriented effect can be represented in terms of inferences, which can lead to a commitment (an attitude of the individual towards a judgment or a state of affairs, see Hamblin, 1970; Walton \& Krabbe, 1995) or in more complex patterns, leading to further inferences. The passage from a value judgment to a specific commitment can be represented in the following scheme of argument from values (Walton et al., 2008, p. 321).

\section{Argumentation scheme 3: Argument from Values}

\begin{tabular}{l|l}
\hline Premise 1 & $\begin{array}{l}\text { The state of affairs } x \text { is positive/negative as judged by Agent } A \text { according to Value } V \\
\text { (value judgment). }\end{array}$ \\
\hline Premise 2 & $\begin{array}{l}\text { The fact that } x \text { is positive/negative affects the interpretation and therefore the } \\
\text { evaluation of goal } G \text { of agent } A \text { (if } x \text { is good, it supports commitment to } G \text { ). }\end{array}$ \\
\hline Conclusion & $\begin{array}{l}\text { The evaluation of } x \text { according to value } V \text { is a reason for retaining/retracting } \\
\text { commitment to } G .\end{array}$ \\
\hline
\end{tabular}

The object of the commitment is generically represented as a Goal, which can refer to a generic end towards which an action can be directed (approval or disapproval) or a specific one (supporting a candidate or voting against him). For example, the use of the term "politically correct" for describing one's behavior can be normally considered as a reason for approving of her, or at least of her behavior. On the contrary, describing a person as "scum" provides a reason for evaluating him or her negatively as worthless, leading to disapproval.

This generic commitment can become more specific by drawing the possible actions that can pursue the goal of the agent. Practical reasoning and reasoning from consequences (von Wright, 1963a, 1963b, 1972) can be represented as schemes of inference connecting a desired situation - or rather a "declaration of intention," a commitment to bringing about a state of affairs - with conditions. In the first case, the agent can reason by selecting (committing to) the productive or necessary means for bringing about the desired state of affairs (the best way of disapproving of Clinton is not to vote her). In the other type of reasoning, called argument from consequences, the agent only considers one relationship between a desirable or undesirable state of affairs to the action that is the necessary or productive cause thereof. This inference can be represented as follows (Walton et al., 2008, pp. 332-333). 
Argumentation scheme 4: Argument from consequences.

\begin{tabular}{l|l}
\hline PREMISE 1 & $\begin{array}{l}\text { If action } Q \text { is brought about, good (bad) consequences will } \\
\text { plausibly occur. }\end{array}$ \\
\hline Premise 2 & $\begin{array}{l}\text { Good (bad) consequences are (not) desirable (should (not) } \\
\text { occur). }\end{array}$ \\
\hline Conclusion & Therefore, $Q$ should (not) be brought about. \\
\hline
\end{tabular}

For example, this type of reasoning underlies the passage from the negative evaluation of an individual labeled as "politically correct" or "scum" and his or her possible future actions (politically correct people do not offend others/are good at diplomacy; if someone is scum, he is worthless) to a specific action (I should support him or her; I should despise him or her).

This inferential framework can be used for investigating some famous uses of emotive terms in Trump's campaign, pointing out the strategies used.

\section{Using Emotive Words to Craft Emotions}

The most prototypical example of use of emotive words to steer the audience's emotions and evaluation of a state of affairs consists in the use of slurs. For example, we consider the following excerpt from Trump's campaign rally in Hilton Head Island, South Carolina, ${ }^{5}$ in which he describes the journalists:

\section{Case 1: Scum and other slurs ${ }^{6}$}

They're scum. They're horrible people. They are so illegitimate. ... Some of the people in the press are honorable. But you've got $50 \%$ who are terrible people. [...]

I would never kill them, but I do hate them. And some of them are such lying, disgusting people. It's true.

In particular, "scum" is a lexicalized metaphor, a slur whose definition includes an evaluation of the subject matter (very bad or immoral person) (Hom, 2008). Other adjectives ("horrible," "terrible," "disgusting") are purely evaluative, namely provide an assessment of the name modified, which is described referring to the emotion that is encouraged (fear, unpleasantness, disgust). Finally, words such as "illegitimate" or "lying" can be considered as properly "ethical words," i.e. words that describe a state of affairs without involving in their definition any evaluative component ("not accepted by the law as rightful;" "not telling the truth").

\footnotetext{
${ }^{5}$ Transcript retrieved from http://www.kansascity.com/news/local/news-columns-blogs/thebuzz/article55604115.html (Accessed on 01 September 2020).

${ }^{6}$ Rick Hampson (2016). Donald Trump's attacks on the news media: A not-so-short history. USA Today 10 March 2016. Retrieved from: http://www.usatoday.com/story/news/politics/onpolitics/2016/03/10/donald-trump-versus-the-media/81602878/ (Accessed on 01 September 2020).
} 
The distinct types of emotive words lead to inferences different in effectiveness, defeasibility, and force, depending on the presumptions relied upon. "Scum," horrible," "terrible," "disgusting" are used by taking for granted the classificatory criteria underlying their assertion (linguistic presumptions), leading to the inferential structure represented in Table 1 below.

In contrast with the aforementioned emotive words, the adjectives "illegitimate" and "lying" carry a value judgment indirectly (Bentham, 1824, pp. 213-200; Walton, 1999, pp. 130-137). The evaluative inference triggered by them is distinct from the one on which the attribution of the predicate is based. In other words, the linguistic presumption underlying the conventional meaning is distinct from the evaluative one (presumption 3) and can be represented in Table 2 below.

Table 1 Describing the inferential structure of "scum"

Reasoning from classification

1. A low and worthless person is scum (Pres. 1).

2. The speaker has reasons to believe that (or it is common knowledge that) journalists have committed actions that makes them low and worthless people.

3. Journalists are scum.

Evaluative classification

4. A scum is a low and worthless person (Pres. 1).

5. (from 3 and 4) Journalists are low and worthless people.

Reasoning from values

6. (from 5) According to the value of dignity and honor, journalists are considered as extremely low.

7. People characterized by low dignity and honor are inferior and can be dangerous, justifying avoidance and neglect (Ben-Ze'ev, 2000, p. 390) (Pres. 2).

8. (from 3, 6, and 7) The classification of journalists as scum is a reason for avoiding and neglecting them.

Table 2 Describing the inferential structure of "lying"

Reasoning from classification

1. Who is not telling the truth intentionally to deceive is a lying person (Pres. 1).

2. If the speaker classifies someone as "lying", he has reasons to believe that he has a habit of not telling the truth intentionally to deceive.

3. Journalists are lying people.

Evaluative classification

4. Lying people are unethical and dangerous (Pres. 3).

5. (from 3 and 4) Journalists are unethical and dangerous.

Reasoning from values

6. (from 5) According to the value of truthfulness, journalists are considered as extremely low.

7. People characterized by low truthfulness are inferior and can be dangerous, justifying avoidance and neglect, i.e. contempt (Ben-Ze'ev, 2000, p. 390) (Pres. 2).

8. (from 3, 6, and 7) The classification of journalists as lying people is a reason for avoiding and neglecting them (despising them). 
In this analysis, the defeasibility conditions of the first classificatory inference appear more clearly. Trump uses the epithet "lying" without providing any reason therefore. Thus, the burden of providing reasons for the classification is not avoided, but taken for granted as fulfilled and shifted onto the interlocutors (Macagno \& Walton, 2014, Chap. 5).

In Case 1 above, we notice that the emotive meaning can be associated with a term in different fashions. Apart from slurs, some of which at least carry an evaluative component in their definition, and evaluative adjectives, Trump uses metaphors and "ethical" words. Metaphors in particular, carry with them the common ground commonly associated with the vehicle (Clark, 1996; Kovecses, 2015, pp. 179-180; Ritchie, 2006, pp. 88-96), namely the frame or the script (Samet \& Schank, 1984) that is activated, or the context in which it has been previously or prototypically used (Clark, 1996, pp. 38-41; Kovecses, 2015, pp. 180-181; Ritchie, 2006, pp. 190-191). In this sense, such previous contexts make specific accidental properties (evaluative) or inferences salient, i.e. accessible because of their conventionality, frequency, familiarity, or prototypicality (Giora, 2003, 2008). For this reason, a metaphor can lead to associations and inferences that can trigger emotions, as pointed out in Port Royal Logic (Arnauld \& Nicole, Logic, Chapter I, 13). A clear example of the use of metaphors for arousing emotions can be found in the aforementioned speech given by Trump in South Carolina

\section{Case 2: Behemoth}

I order thousands of televisions, they're all from South Korea. So we have 28,000 people on the border separating South Korea from this maniac in North Korea, we get nothing. What do - we get nothing. They're making a fortune. It's an economic behemoth. [...]

A lot of you don't know we protect Germany. Germany! Mercedes Benz, how many people have a Mercedes Benz? We protect Germany. It's an economic behemoth.

Here, "behemoth" is used not only for referring to Germany or South Korea using the image of the biblical mighty beast. ${ }^{7}$ More importantly, the common ground associated with the vehicle due to the previous narrations (monster provoking chaos; monster destroying and eating the world) leads to negative assessments of the targets, leading to immediate emotional responses (danger, ergo fear). The use of this metaphor involves both a classificatory reasoning, based on the premises that Trump shortly provides (they are making a fortune; thousands of TV; etc.) and the common description of "behemoth" (Pres. 1), and a distinct evaluative one, based on the commonly shared actions it performs (Pres. 2 and 3). This reasoning can follow the pattern of the Argumentation scheme 2: (1) A behemoth is a monster eating the world, and (2) since this is a terrible consequence, (3) a behemoth is also a terrible and hateful being.

\footnotetext{
${ }^{7}$ The common ground associated with "behemoth" is usually an entity bigger than it should be (Robert Stevens, 2018. Opinion: Don't build this behemoth of a project in Villa Hills, USA Today May 8, 2018, Retrieved from https://eu.cincinnati.com/story/opinion/2018/05/08/opinion-dontbuild-behemoth-project-villa-hills/566292002/ (Accessed on 30 May 2020).
} 
A similar strategy is used for eliciting the emotive response of anger (Ben-Ze'ev, 2000 , p. 380) by depicting a state of affairs as an undeserved offence. Trump describes the United States as a "dumping ground" in which the world is depositing their garbage, i.e. the migrants:

\section{Case 3: Dumping ground}

And we're like a dumping ground for the world. We're a dumping ground. They want to take these migrants - the migrants, you know, and I feel terrible about the migration, caused by Hillary Clinton and Barack Obama. They're the ones that caused it. They go into Libya. They knocked the hell out of Gadhafi. OK, so Gadhafi - they backed rebels who end up killing the ambassador and the other young people.

In addition to implicitly labelling the migrants as "garbage," provoking the evaluation of inferiority which is the basis of contempt (Ben-Ze'ev, 2000, p. 390), Trump presents the problem of migration as an offence of littering the property of the Americans. The emotive words are then connected with the offenders (Obama and Clinton) who can thus become the objects of anger.

In addition to metaphors, also similes can trigger similar emotive effects. In the following case, Trump emotionally describes his Republican competitor, Marco Rubio, as "weak like a baby." The word "baby" has no negative emotive meaning; however, Trump uses to reinforce the evaluation of the opponent as weak, relying on the concept of helplessness usually associated to a baby. This simile, however, presents Rubio as a helpless baby, which is in striking contrast with the position he is aiming at, resulting in contempt and ridicule: ${ }^{8}$

\section{Case 4: Baby}

Nice person, weak on illegal immigration ... like, weak like a baby. Like a baby. Not a good poker player, because every time he's under pressure he just starts to profusely sweat. If he was playing poker with me, I'd say 'Ah!' The water would start pouring off his body.

The inferential structure of metaphors has the great advantage of providing clear evaluative premises associated with them (a dumping ground is a despicable place), but unclear definitional characteristics, as the vehicle is in itself implicitly redefined (Macagno \& Walton, 2014). For example, "dumping ground" can be understood as meaning a place where unwanted beings or entities are collected, but this definition is not necessarily shared, nor is it stated, allowing Trump to use the term without justifying it. In this sense, the weakness of the linguistic presumption is exploited by the speaker to limit the possibilities of being criticized.

These cases are all characterized by evaluative premises that can justify the triggering of an emotion, such as contempt (Case 1 and 4), fear (Case 2), or rage (Case $3)$. When ethical words trigger emotional responses, they contribute to judgment and belief creation. However, such emotional judgments and beliefs are hasty and

\footnotetext{
${ }^{8}$ Margaret Hartmann (2016). Trump Explains Why Rubio Is 'Weak Like a Baby,' and Other Hits From His 95-Minute Rant. The New York Magazine, 13 November 2015. Retrieved from http:// nymag.com/daily/intelligencer/2015/11/best-of-trumps-95-minute-rant-compilation.html (Accessed on 01 September 2020).
} 
biased, leading to automatic conclusions of right and wrong (Damasio, 1994; Greene \& Haidt, 2002; Keltner \& Lerner, 2010, p. 331), which in turn are at the basis of a sudden action tendency (depending on the intensity of the emotion), an automatic, time-tested responses, requiring low processing efforts (Loewenstein \& Lerner, 2003, p. 628). Within moral psychology, this relation between emotion and moral judgment has been explored, inter alia, by Jonathan Haidt (2001; Haidt \& Hersh, 2001; Wheatley \& Haidt, 2005). According to Haidt, when we assess moral issues, we almost never behave like a judge who seeks the truth by objectively assessing arguments and evidence. Instead, we act as lawyers: we already have a preferential viewpoint, a conclusion that we intend to support by means of evidence. Thus, we proceed in search of evidence that might persuade the others of the truth of our opinion (Haidt, 2001; Rossi, 2012). The rhetorical effectiveness of the political examples discussed above clearly illustrates this description. In these cases, ethical words trigger emotional responses, which are, from an argumentative point of view, shortcuts of the inferential reconstruction of micro-arguments described in the previous section. Ethical words thus provide or suggest an evaluation that activates a pattern of automatic (heuristic) reasoning (Chen \& Chaiken, 1999; Kahneman, 2003, 2011; Petty \& Cacioppo, 1986), which has devastating effects on the critical (systematic) assessment to the described or referred state of affairs (Blanchette \& Richards, 2004; Loewenstein \& Lerner, 2003).

\section{Manipulating the Definition of Emotive Words}

The "wedding" of descriptive and emotive meaning in ethical (emotive) words leads to a dangerous possibility, namely the use of an emotive word to refer to a state of affairs that is normally assessed neutrally, or even in a way different from the emotive meaning of the term used (Arnauld \& Nicole, Logic, Chapter I, 13). This possibility is rooted in the redefinition of the emotive word, i.e. in the strategy that Stevenson named persuasive definition (Macagno \& Walton, 2008, 2010; Stevenson, 1938b). Persuasive definitions are explicit or implicit redefinitions of ethical words, aimed at redirecting the emotive meaning on a different state of affairs, which would not be normally predicated of such a word. For example, by redefining "culture" as originality, the speaker can change "interests by changing names," redirecting the interlocutor's evaluation of their referents and his related emotions (Macagno \& Walton, 2014; Stevenson, 1938b, p. 332).

Trump uses this strategy very clearly in his aforementioned speech. In particular, he does not redefine an emotive word; instead, he uses a term ("deal") commonly used in business to mean a transaction, an arrangement for mutual advantage, to refer to diplomatic negotiations. However, as in the case of metaphors mentioned above, this term carries an additional emotive meaning resulting from its previous and common contexts of use. A deal is related to money, business, private interests, 
and in particular to private economic advantages, which are incompatible with the public interests defended in diplomatic negotiations. The effect is the following:

\section{Case 5: Deal}

These are people that have deceived us. They've lied to us. They're a terrorist state. But and I used to say it's the worst deal that I've ever seen negotiated. And by the way, just to finish prisoners. So they'd come back; we get our prisoners. But then when I hear the other day that now this deal is done. It's all done. [...] Now, we've already taken off the sanctions. They're already rich as hell. What — what's going on there? That's why I say, I mean, some people say it's worst than stupidity. There's something going on that we don't know about. I mean, honest. And you almost think - I'm not saying that, and I'm not a conspiracy person. As you said, "We are; we're saying it."

Trump is using the term "deal" to refer to a practice (negotiations between nations) that falls outside the ordinary definition of this term (agreement for mutual advantage). In this case, we notice that the strategy pursued is based on a conflict of presumptions. The generic linguistic presumption governing the use of "deal" is contrasted with the evidence of its repeated use by Trump to refer to political negotiations (Pres. 0), which leads to a different, specific one. However, the factual presumption that in deals the agents are pursuing their own private interests is maintained and indeed reinforced by the pragmatic presumption that the text is intended to denounce the dealmakers (Pres. 0). In this sense, it is not replaced by the factual ones characterizing political discussions. The inferential structure can be reconstructed in the following Table 3.

Through this persuasive definition, Trump acts based on a linguistic presumption that is introduced contextually through various uses of this word and the similarity with the commonly shared one, modifying the common ground (Kecskes \& Zhang, 2013) and thus avoiding the burden of proving the reasonableness of his classification.

Table 3 Describing the inferential structure of "deal"

Reasoning from classification

1. A deal is an agreement for mutual advantage (Pres. 1).

2. Democrats have made deals (stated).

3. Trump uses "deal" in a sense different from "agreement for mutual advantage" as "pursuing one's own interests also damaging the others." (from the conclusion of 1 and 2 and the textual evidence).

Evaluative classification

4. Who makes a deal, he or she pursues his own interests also damaging the others (Pres. 2; evidence from the text).

5. (from 3 and 4) Democrats pursued their own interests also damaging the others.

Reasoning from values

6. (from 5) According to the value of fairness, democrats are considered as extremely low.

7. People characterized by low fairness can be dangerous and unjust, justifying rage (Pres. 2).

8. (from 3, 6, and 7) The classification of democrats as dealmakers is a reason for being upset for and disgusted by their behavior. 


\section{Crafting Emotive Meaning}

The use of emotive words exploits the evaluative inferences that can be conceived as based on linguistic, factual, or evaluative presumptions. Persuasive definitions are grounded on a more complex structure, consisting in altering the linguistic presumptions characterizing the shared use of a word. A more complex strategy, called quasi-definition, consists in the modification of the evaluative or factual presumptions that are associated with the use of a word. As persuasive definitions, quasi definition are also characterized by a conflict of presumptions. Evaluative or factual presumptions can be associated with the use of a term by placing it in a context in which it can be interpreted only as a derogatory or praising expression (a pragmatic presumption), and needs to be justified by introducing the presumption that the referent is in fact negative or has done something negatively evaluated.

A clear example can be drawn from Trump's campaign. One of his most successful rhetorical moves was the modification of the emotive meaning of "politically correct." This phrase is not commonly perceived as necessarily derogatory, even though the history of its use reveals how it commonly suggested a view characterized by Stalinist orthodoxy. ${ }^{9}$

However, Trump used it in contexts in which it could be only interpreted as meaning an insincere, uncommitted, and even coward person, referring to his political opponents. Politically correctness was identified by Trump as a problem during the first Republican debate in August, when he answered to the attack by the moderator on comments that he had made disparaging women. ${ }^{10}$

\section{Case 6: Political correctness as the problem (waste of time)}

I think the big problem this country has is being politically correct [...] I've been challenged by so many people, and I don't frankly have time for total political correctness. And to be honest with you, this country doesn't have time either. This country is in big trouble. We don't win anymore. We lose to China. We lose to Mexico both in trade and at the border. We lose to everybody.

Politically correctness is here characterized as a problem, and contrasted with serious occupations (I don't have time) and more importantly with addressing national interests and solving big troubles (this country doesn't have time either). The pragmatic presumption is that Trump is criticizing politicians for their political correctness, and for this reason a new presumption needs to be introduced connecting political correctness with despicable properties. In this sense, Trump implicitly quasi-defines it as a practice that is usually carried out as a non-serious waste of

\footnotetext{
${ }^{9}$ Philip Bump (2015). How 'politically correct' moved from Commies to culture and back into politics. The Washington Post, 17 December 2015. Retrieved from https://www.washingtonpost. $\mathrm{com} /$ news/the-fix/wp/2015/12/17/the-interesting-evolution-of-political-correctness/?utm _ term $=.38$ cf66c867ed. (Accessed on 01 September 2020).

${ }^{10}$ Karen Tumulty and Jenna Johnson (2016). Why Trump may be winning the war on 'political correctness.' The Washington Post, 4 January 2016. Retrieved from https://www.washingtonpost. com/politics/why-trump-may-be-winning-the-war-on-political-correctness/2016/01/04/098cf832afda-11e5-b711-1998289ffcea_story.html?utm_term=.0f77f4556e35. (Accessed on 01 September 2020).
} 
time, a distraction from facing real problems, which characterises a group to which he, the non-politically correct one, does not belong at all.

Trump uses the pragmatic presumption (summarized in the conclusion, 9) for taking for granted that political correctness is presumed by everyone to lead to a dangerous waste of time (presumption 2). In this fashion, he modifies the evaluation of the term within this specific context.

The quasi-definition of political correctness is achieved by placing the phrase in other contexts, in which the purpose is not attacking a policy or arousing indignation against some politicians, but rather ridiculing the opponent, triggering emotions of contempt. In describing how Rubio and Bush praise each other publicly, mimicking their expressions of mutual esteem, he claimed the following:

\section{Case 7: Political correctness as hypocrisy}

Rubio and Bush "hate each other," Trump said, blasting Rubio as "overly ambitious, too young, and I have better hair than he does, right?" "But I am so tired of this politically correct crap." 11

So many "politically correct" fools in our country. We have to all get back to work and stop wasting time and energy on nonsense! ${ }^{12}$

"Politically correct" was implicitly quasi-defined by suggesting the same inferences as above based on the presumed premise that it leads to (and justifies) useless waste of time. However, here Trump presupposes another implicit premise, namely that political correctness is used to hide real beliefs.

The most effective speech quasi-defining "politically correct" as "a serious problem" was delivered after a Muslim gunman killed 49 people at a gay nightclub in Orlando. ${ }^{13}$ Trump identifies the problem that led America to incurring dramatic consequences with being "politically correct:"

\section{Case 8: Politically correct as the problem (danger and foolishness)}

The Obama Administration, with the support of Hillary Clinton and others, has also damaged our security by restraining our intelligence-gathering and failing to support law enforcement. They have put political correctness above common sense, above your safety, and above all else. I refuse to be politically correct.

This example can be reconstructed through an analysis similar to the inferences from consequence to an evaluation and the reasoning from values illustrated in Table 4. Trump here explicitly presents "political correctness" as a principle, or objective, opposite to or at least alternative to common sense and the Americans'

\footnotetext{
${ }^{11}$ Nick Gass (2015). Trump: I'm so tired of this politically correct crap. Politico 23 September 2015. Retrieved from http://www.politico.com/story/2015/09/donald-trump-politically-correctcrap-213988 (Accessed on 01 September 2020).

${ }^{12} \mathrm{https} / / /$ twitter.com/realdonaldtrump/status/629992743788523520

${ }^{13}$ Donald J. Trump Addresses Terrorism, Immigration, and National Security. Retrieved from https://www.donaldjtrump.com/press-releases/donald-j.-trump-addresses-terrorism-immigrationand-national-security (Accessed on 01 September 2020).
} 
Table 4 Describing the inferential structure of "politically correct"

Reasoning from classification

1. Political correctness is the avoidance of forms of expression or action that are perceived to exclude, marginalize, or insult groups of people (Pres. 1).

2. Politicians usually avoid insulting or excluding groups of people (Pres. 2).

3. Politicians are politically correct.

Consequence to evaluation

4. Political correctness causes dangerous waste of time (Pres. 2, justifying Pres. 0; evidence from the text).

5. Dangerous waste of time is extremely negative, as it is sign of lack of will and indifference for the nation (Pres. 3).

6. (from 4 and 5) Political correctness is extremely negative as it is sign of lack of will and indifference for the nation.

Reasoning from values

7. (from 3 and 6) According to the values of duty and will, politically correct politicians are considered as extremely low.

8. Poorly determined politicians indifferent to their own nation can be dangerous and inferior, justifying contempt (Pres. 2).

9. (from 3, 7, and 8) Politically correct politicians should be despised.

safety, and is illustrated with the Obama's Administration decision to restrain "intelligence-gathering" and fail "to support law enforcement."

In a fourth instance, "political correctness" is presented as the cause of the inability to respond to the attacks:

\section{Case 9: Politically correct as a hindrance (inability to act)}

We need to respond to this attack on America as one united people - with force, purpose and determination. But the current politically correct response cripples our ability to talk and think and act clearly. [...] If we do not get tough and smart real fast, we are not going to have a country anymore. Because our leaders are weak, I said this was going to happen and it is only going to get worse. I am trying to save lives and prevent the next terrorist attack. We can't afford to be politically correct anymore.

Trump here relies on the inference from consequences to evaluation, presenting political correctness as negative because resulting in inability act and react. The presumption that Trump introduces as shared is that politically correct people are only interested in pursuing their own interests and avoiding getting involved in problematic issues, even to the detriment of the whole country.

All the aforementioned negative characteristics of the new emotional meaning of "politically correct" were enhanced by associating them with the idea of injustice or deceit, which triggers emotions such as rage or indignation ${ }^{14}$ :

\footnotetext{
${ }^{14}$ Moira Weigel (2016). Political correctness: how the right invented a phantom enemy. The Guardian, 30 November 2016. Retrieved from: https://www.theguardian.com/us-news/2016/ nov/30/political-correctness-how-the-right-invented-phantom-enemy-donald-trump (Accessed on 3 February 2020).
} 


\section{Case 10: Politically correct as a deceit}

That is the choice I put before the American people: a mainstream immigration policy designed to benefit America, or Hillary Clinton's radical immigration policy designed to benefit politically-correct special interests.

Here, special interests, i.e. the interests (usually economic) of a specific group influencing the government and opposed to the interests of the whole population, are associated with the already quasi-defined concept of politically correct. Trump's choice to refer to the "special interests" by qualifying them as "politically-correct" can be reconstructed by taking for granted the presumption that political correctness is used as an instrument for justifying to the public a policy detrimental to the American people. Trump considers this premise as commonly shared, which leads to the evaluative inference that political correctness is negative because deceitful.

From these example, we notice two crucial features of emotive meaning. First, emotive meaning can be altered by means of re-contextualization, namely placing the term or phrase in a context different from the one in which it was used before or it is commonly used. By re-contextualizing the "politically correct," Trump links it with a set of negative characteristics (evaluative and factual presumptions), and then uses it to attack his opponents and silence the challenges to his aggressive, racist, or womanizer behaviour. Second, the modification of emotive meaning is achieved implicitly. Trump never states that politically correct people are hypocrites (or bad for other reasons). This evaluative judgment is only implied. The hearer draws the evaluative inference necessary for making the phrase relevant to the context. For example, without this intended inference, it would be impossible to explain why in Case 7 the speaker uses it as an adjective specifying two concepts clearly and commonly negatively evaluated ("crap" and "fools") and uses the corresponding sentences as a premise for concluding that American needs to "stop wasting time and energy on nonsense." Without the bridging inference (Clark, 1977, pp. 247-248; Haviland \& Clark, 1974) that "politically correct" is a problem (or more specifically useless hypocrisy), Trump's argument would not make much sense. This inferential aspect of emotive meaning can account also for the fact that the aforementioned recontextualizations are effective in specific contexts. Before a different public (not supporting Trump or not disapproving the existing administration), the evaluative difference would have been difficult to accept, and the sequence of discourse hardly considered as reasonable.

\section{Crafting Heuristics. Connotation and Emotive Meaning}

In sections "Using Emotive Words to Craft Emotions", "Manipulating the Definition of Emotive Words", and "Crafting Emotive Meaning", we showed how ethical words can be used for eliciting an "affective" (using Stevenson's terminology) or rather emotional response, and how the "tendency" to be used for this purpose can be modified. In section "Crafting Emotive Meaning" we pointed out how in his speeches, 
Trump alters the "emotive meaning" of the otherwise neutral or positively evaluated concept of "politically correct." He does not use the word improperly, namely he does not redefine it (as he in contrast did with "deal"). However, he changes the prototypical context in which it is used, using the phrase to convey negative evaluative inferences. The repeated use of this strategy changes the emotive meaning of the phrase, and makes it as stably associated with negative evaluative inferences.

The relative stability of the "emotive meaning" of ethical words in different contexts appears to be an automatic or automatized process parallel to conversational implicatures (Capone, 2011; Macagno, 2017; Nunberg, 2017). Apart from questionbegging epithets - characterized by evaluative semantic properties - the majority of emotive words analyzed above are characterized by inferences drawn also from the assessment of the state of affairs referred to. The process of "emotivization" (or associative engineering, see Leech, 1981, p. 46) of a word described in section "Crafting Emotive Meaning" suggests how evaluative inferences can become gradually automatized. This process can be investigated in terms of connotation, or rather, a specific account of connotation.

The connotative meaning of the majority of the aforementioned emotive words can be considered as resulting from the uses of the term, acquiring an additional meaning triggered not directly by its relationship with its definitional features (and the referent), but as a sign used within a linguistic system or a context. Connotation can be represented as a distinct, but not independent, level of meaning of a sign, using the terminology of Hjelmslev (1969; Kerbrat-Orecchioni, 1977; Molino, 1971) (Fig. 2).

The sources of the connotative meaning can be different, including ideological, axiological (value judgment) and emotive characteristics (Kerbrat-Orecchioni, 1977, p. 167) that can convey value judgments that can trigger emotional responses (Cato et al., 2004). These non-definitional features can be the result of the use of a term in a specific utterance to pursue a specific purpose, such as the aforementioned uses of the phrase "politically correct" by Trump. However, this contextual meaning - which we have investigated in terms of inferences - can become integrated at a cultural level (Garza-Cuarón, 1991, pp. 213-214). The context can become culturally associated with the use of a specific term, which acquires a more stable connotative meaning (Kerbrat-Orecchioni, 1977, p. 119). In a sense, the lexical items "encapsulate" prior contexts of experience: "they carry context (prior context), encoding the history of their prior use (prior context) in a speech community"

\begin{tabular}{|l|c|c|}
\hline \multicolumn{2}{|c|}{ Expression (sign) } & Content \\
\hline Expression & Content & \\
\hline
\end{tabular}

Level of

Connotation

Level of

Denotation

Fig. 2 Representing connotation 
(Kecskes, 2008, 2013, p. 129; 131; Kecskes \& Zhang, 2009). As Kecskes put it (Kecskes, 2013, p. 133):

Lexical items encode the history of their use, which basically creates a record of prior contexts. They trigger frames and cultural models that the interlocutor has experienced before. [...] Linguistic units encapsulate the history of their use, i.e., the situations in which they have been used. What happens in communication is that prior context encoded in the utterances interplays with the actual situational context, and this interplay results in what we call "meaning."

In particular, Kecskes points out a dimension of meaning (which involves "wordspecific elements" and "culture-specific conceptual properties," see Cruse, 1992; Kecskes, 2003:40-43) distinct from the semantic (definitional, or better conceptual) one. We can draw a correspondence between the first dimension (including both lexicalized and cultural properties of a lexical item) and the "emotive meaning," and between the second (conceptual) dimension and the "descriptive meaning" (Leech, 1981, p. 12). They jointly constitute what Kecskes refers to as "coresense," namely "a summary of the most familiar, regular, typical, and (generally, but not always) frequent uses of a word. It reflects the history of use of the word and is the common core information that was called public context above, usually shared by members of a speech community" (Kecskes, 2013, p. 141).

This account of connotative or rather contextual (parole) nature of emotive meaning leads to the problem of explaining the mechanisms underlying how it is generated and stabilized in terms of stereotypical inferential patterns (Capone, 2011; Macagno, 2017). A possible explanation can be found in Ducrot's notion of topos. According to Ducrot, an utterance can be described as a bundle of topoi, namely argumentative connections representing instructions such as "uttering $\mathrm{x}$, the conclusion y is supported" (Anscombre \& Ducrot, 1983; Ducrot, 1979). As a consequence, words can be described not starting from previous knowledge of reality (their "descriptive meaning") but considering their discursive (argumentative) potential (Ducrot, 1984, 1993). Such topoi, or argumentative contents, are considered by Ducrot as presuppositions, namely (in his theory) the content of illocutionary acts of presupposition (Anscombre \& Ducrot, 1983, p. 49).

The theory of topoi can explain the heuristic judgments that ethical words trigger. For example, we consider some of the cases illustrated in previous section. By referring to journalists as "liars" in Case 1, Trump triggers automatically the judgment that journalists are despicable and should not be trusted, based on the heuristic or topos that, "if someone is a liar, he is untrustworthy and contemptible person." Similarly, other words commonly used in a pejorative sense, such as "behemoth" or "dumping ground," can be analyzed in terms of culturally stabilized argumentative inferences. Such "pejoratives" are hardly considered as insults; however, the use in specific contexts to elicit negative conclusions has stabilized the inferences that a hearer can heuristically draw from them (to be dangerously aggressive; to be besmeared by $x$ ).

The analysis of emotive meaning in terms of connotation and topoi can also explain the process of emotivization referred to as "quasi-definition." As shown in the section above, Trump implicitly quasi-defines "politically correct" by present- 
ing this description as the reason of distinct but related negative value judgments. In Case 6, "politically correct" is presented as conflicting with "solving the problems" (if I am politically correct, I cannot/do not have the time to solve more serious problems) taking for granted that political correctness is not serious. In Case 7, "politically correct" is used taking for granted the premise that "people use political correctness to hide their lack of courage." In Case 9, the implicit premise is that "political correctness is the cause of inability to act," while in Case 10 Trump takes for granted that, "political correctness is a way for justifying to the public a policy detrimental to the American people." The most effective context in which this phrase is used for introducing topoi to negative value judgments is Case 8. In a highly dramatic context (a shooting), Trump took for granted that "political correctness" led to security failures. Clearly, all the aforementioned reconstructions are possible interpretations; what matters is that these tacit premises are similar in kind, and their repeated use as commonly shared contributes to create common ground topoi associated with this phrase. The evaluative inferences become thus automatized due to their repeated use.

From a logical perspective, the process of automatization of evaluative inferences can be described as the passage from the "quality" of one or more specific instances (for example, of a "politically correct person") to the "characteristic" of a kind (the "politically correct") (Dewey, 1938, p. 292). In this sense, emotive force can be regarded as a continuum between the inference drawn from a specific word use to its lexicalization as a property (a feature drawn from the definition of a term, such as "receiving unwanted items" from "dumping ground") or definitional trait ("being worthless" from "scum"). This continuum can also account for the different "cancellability" conditions of emotive meaning depending on the "ethical word" considered.

\section{Conclusion}

This paper addresses the argumentative structure of the emotive meaning of "ethical" or "emotive" words, investigating how it can be represented, how it is related to emotions, and how it is generated or manipulated. Ethical words are analyzed starting from Stevenson's approach to meaning, which distinguishes the descriptive (definitional) meaning from the emotive one. These two dimensions can be represented in terms of the intended inferences conveyed by the use of a word. In particular, ethical words are used to trigger classificatory and practical inferences, which can be critically evaluated using argumentation schemes. By the use of such schemes, it is possible to account for both components of the "expressive force," namely an evaluation and an action-related dimension. We maintained that both dimensions can be investigated in terms of presumptions, leading to a stereotypical evaluation and a typical communicative act performed by such words (denigrating the interlocutor, for instance). This twofold (evaluative and pragmatic) presumption explains the complex nature of the expressive meaning. 
We maintain that emotive meaning can be considered as the result of an evaluative inference (Nunberg, 2017) that has become commonly associated with the use of an ethical word. Emotive meaning can be represented by reconstructing the micro-arguments involved in the use of an ethical word through patterns of arguments called argumentation schemes. The schemes are used for reconstructing the content of the intended inferences, whose presence is commonly identified through pragmatic maxims. In this sense, our focus is not on how the existence of an intended inference is signaled, but on how it can be reconstructed independently of its being automatic or systematic. This analysis has two relevant characteristics. First, it accounts for specific and limited types of conclusions that can be drawn from the use of an ethical term (accounting for the stability and at the same time the variability and ineffability of evaluative judgments that speakers can draw from the use of an ethical term). Second, since argumentative inferences can become automatically (heuristically) processed, it can explain the limited defeasibility of emotive meaning.

The description of emotive meaning as automatized inferences can explain also the historical variability of ethical terms. Ethical words can be quasi-defined, namely associated with a new or different emotive meaning. This quasi-definition is claimed to consist in the use of the target term in specific contexts that can evoke emotions or intense value judgments. In this fashion, the ethical word is presented as the premise of similar or related evaluative conclusions. The re-contextualization ends when the new inferences become associated more stably with the use of the ethical word, namely when the implicit premises that before were potentially controversial become part of the "bundle of topoi" associated with the term.

On this perspective, connotation is regarded as a set of inferences commonly drawn from habitual uses of a term. The repeated use of the quasi-defined term in similar contexts reinforces the association between the word and the emotion or the value judgment, namely the specific "prior context" that is carried with the ethical word (the context that the linguistic expression creates) and is used for its interpretation (Kecskes, 2013, p. 135; Mey, 2006). Clearly, this inferential contextualization is possible because the premises warranting the evaluative conclusions are taken for granted by the speaker and not challenged by the interlocutors or hearers. On this perspective, the act of introducing a new connotation of words (quasi-definition) becomes an act of manipulating the common ground (Macagno, 2012b, 2015; Macagno \& Walton, 2014).

Acknowledgments This work was supported by the Fundação para a Ciência e a Tecnologia (research grants no. SFRH/BPD/115073/2016 and PTDC/FER-FIL/28278/2017).

\section{References}

Anderson, L., \& Lepore, E. (2013). What did you call me? Slurs as prohibited words. Analytic Philosophy, 54(3), 350-363. https://doi.org/10.1111/phib.12023.

Anscombre, J.-C., \& Ducrot, O. (1983). L'argumentation dans la langue. Bruxelles, Belgium: Pierre Mardaga. 
Aristotle. (1991). Topics. In J. Barnes (Ed.), The complete works of Aristotle (Vol. I). Princeton, NJ: Princeton University Press.

Arnauld, A., \& Nicole, P. (1662/1996). Logic or the art of thinking. (J. V. Buroker, Ed.). Cambridge, UK: Cambridge University Press.

Atlas, J. D., \& Levinson, S. (1981). It-clefts, informativeness and logical form: Radical pragmatics (revised standard version). In P. Cole (Ed.), Radical pragmatics (pp. 1-62). New York, NY: Academic Press.

Bach, K., \& Harnish, R. (1979). Linguistic communication and speech acts. Cambridge, MA: MIT Press.

Bentham, J. (1824). The book of fallacies. London, UK: John and H.L. Hunt.

Ben-Ze'ev, A. (2000). The subtlety of emotions. Cambridge, MA: MIT Press.

Bianchi, C. (2014a). Slurs and appropriation: An echoic account. Journal of Pragmatics, 66, 35-44. https://doi.org/10.1016/j.pragma.2014.02.009.

Bianchi, C. (2014b). The speech acts account of derogatory epithets: Some critical notes. In J. Dutant, D. Fassio, \& A. Meylan (Eds.), Liber Amicorum Pascal Engel (pp. 465-480). Genève, Switzerland: University of Geneva.

Blakemore, D. (2015). Slurs and expletives: A case against a general account of expressive meaning. Language Sciences, 52, 22-35. https://doi.org/10.1016/j.langsci.2014.06.018.

Blanchette, I., \& Richards, A. (2004). Reasoning about emotional and neutral materials - Is logic affected by emotion? Psychological Science, 15(11), 745-752. https://doi. org/10.1111/j.0956-7976.2004.00751.x

Capone, A. (2010). What can modularity of mind tell us about the semantics/pragmatics debate? Australian Journal of Linguistics, 30(4), 497-520. https://doi.org/10.1080/07268602.2010.52 2971.

Capone, A. (2011). Default semantics and the architecture of the mind. Journal of Pragmatics, 43(6), 1741-1754. https://doi.org/10.1016/j.pragma.2010.11.004

Capone, A. (2013). Explicatures are NOT cancellable. In A. Capone, F. Lo Piparo, \& M. Carapezza (Eds.), Perspectives on linguistic pragmatics, perspectives in pragmatics, philosophy \& psychology (Vol. 2, pp. 131-151). Cham, Switzerland: Springer.

Capone, A. (2014). Indirect reports, slurs, and the polyphonic speaker. Reti, Saperi, Linguaggi, 1(2), 299-318. https://doi.org/10.12832/78931.

Capone, A. (2016). The pragmatics of indirect reports: Socio-philosophical considerations. Cham, Switzerland: Springer.

Carston, R. (2002). Linguistic meaning, communicated meaning and cognitive pragmatics. Mind and Language, 17(1\&2), 127-148. https://doi.org/10.1111/1468-0017.00192

Carston, R. (2004). Truth-conditional content and conversational implicature. In C. Bianchi (Ed.), The semantics/pragmatics distinction (pp. 65-100). Stanford, CA: CSLI Publications.

Cato, A., Crosson, B., Gökçay, D., Soltysik, D., Wierenga, C., Gopinath, K., et al. (2004). Processing words with emotional connotation: An FMRI study of time course and laterality. Journal of Cognitive Neuroscience, 16(2), 167-177. https://doi.org/10.1162/089892904322984481.

Chen, S., \& Chaiken, S. (1999). The heuristic-systematic model in its broader context. In S. Chaiken \& Y. Trope (Eds.), Dual-process theories in social psychology (pp. 73-96). New York, NY: Guilford Press.

Clark, H. (1977). Inferences in comprehension. In D. LaBerge \& J. Samuels (Eds.), Basic processes in reading: Perception and comprehension (pp. 243-263). Hillsdale, NJ: Erlbaum.

Clark, H. (1996). Using language. Cambridge, UK: Cambridge University Press.

Clark, H., \& Brennan, S. (1991). Grounding in communication. In L. Resnick, J. Levine, \& S. Teasley (Eds.), Perspectives on socially shared cognition (pp. 127-149). Washington, D.C.: American Psychological Association.

Croom, A. (2011). Slurs. Language Sciences, 33(3), 343-358. https://doi.org/10.1016/j. langsci.2010.11.005.

Croom, A. (2014). The semantics of slurs: A refutation of pure expressivism. Language Sciences, 41, 227-242. https://doi.org/10.1016/j.langsci.2013.07.003 
Cruse, A. (1992). Antonymy revisited: Some thoughts on the relationship between words and concepts. In A. Lehrer \& E. F. Kittay (Eds.), Frames, fields, and contrasts (pp. 289-306). Hillsdale, NJ: Lawrence Erlbaum Associates.

Damasio, A. (1994). Descartes' error: Emotion, reason, and the human brain. New York, NY: Avon Books.

Dancy, J. (2013). Meta-ethics in the twentieth century. In M. Beaney (Ed.), The Oxford handbook of the history of analytic philosophy (pp. 729-749). Oxford UK: Oxford University Press.

Dascal, M., \& Wróblewski, J. (1988). Transparency and doubt: Understanding and interpretation in pragmatics and in law. Law and Philosophy, 7(2), 203-224. https://doi.org/10.1007/ BF00144156.

De Sousa, R. (1987). The rationality of emotion. Cambridge, MA: MIT Press.

Dewey, J. (1938). Logic-the theory of inquiry. New York, NY: Henry Holt and Company.

Druckman, J. (2002). The implications of framing effects for citizen competence. Political Behavior, 23(3), 225-256. https://doi.org/10.1023/A:1015006907312

Ducrot, O. (1979). Les lois de discours. Langue Française, 42, 21-33.

Ducrot, O. (1984). Le dire et le dit. Paris, France: Minuit.

Ducrot, O. (1993). Les topoi dans la "Théorie de l"argumentation dans la langue. In C. Plantin (Ed.), Lieux communs, topoi, stéréotypes (pp. 233-248). Paris, France: Kimé.

Entman, R. M. (1993). Framing: Toward clarification of a fractured paradigm. Journal of Communication, 43(4), 51-58. https://doi.org/10.1111/j.1460-2466.1993.tb01304.x

Garza-Cuarón, B. (1991). Connotation and meaning. Berlin, Germany: De Gruyter.

Geach, P. T. (1965). Assertion. The Philosophical Review, 74(4), 449-465.

Giora, R. (2003). On our mind. Salience, context, and figurative language. Oxford, UK: Oxford University Press.

Giora, R. (2008). Is Metaphor Unique? In R. Gibbs (Ed.), The Cambridge handbook of metaphor and thought (pp. 143-160). New York, NY: Cambridge University Press.

Greene, J., \& Haidt, J. (2002). How (and where) does moral judgment work? Trends in Cognitive Sciences, 6(12), 517-523. https://doi.org/10.1016/S1364-6613(02)02011-9.

Grice, P. (1975). Logic and conversation. In P. Cole \& J. Morgan (Eds.), Syntax and semantics 3: Speech acts (pp. 41-58). New York, NY: Academic Press.

Haidt, J. (2001). The emotional dog and its rational tail: A social intuitionist approach to moral judgment. Psychological Review, 108(4), 814-834. https://doi.org/10.1037/0033-295x.108.4.814.

Haidt, J., \& Hersh, M. (2001). Sexual morality: The cultures and emotions of conservatives and liberals. Journal of Applied Social Psychology, 31(1), 191-221. https://doi.org/10.1111/ j.1559-1816.2001.tb02489.x.

Hamblin, C. L. (1970). Fallacies. London, UK: Methuen.

Haviland, S., \& Clark, H. (1974). What's new? Acquiring new information as a process in comprehension. Journal of Verbal Learning and Verbal Behavior, 13(5), 512-521. https://doi. org/10.1016/S0022-5371(74)80003-4

Hedger, J. (2012). The semantics of racial slurs: Using Kaplan's framework to provide a theory of the meaning of derogatory epithets. Linguistic and Philosophical Investigations, 11, 74-84.

Hjelmslev, L. (1969). Prolegomena to a Theory of Language. Madison, WI: The University of Wisconsin Press.

Hom, C. (2008). The semantics of racial epithets. The Journal of Philosophy, 105(8), 416-440. https://doi.org/10.5840/jphil2008105834.

Hom, C. (2010). Pejoratives. Philosophy Compass, 5(2), 164-185. https://doi. org/10.1111/j.1747-9991.2009.00274.x.

Jaszczolt, K. (2005). Default semantics. Oxford, UK: Oxford University Press.

Kahneman, D. (2003). A perspective on judgment and choice. American Psychologist, 58(9), 697-720. https://doi.org/10.1037/0003-066X.58.9.697.

Kahneman, D. (2011). Thinking, fast and slow. New York, NY: Macmillan Publishing Company.

Kecskes, I. (2003). Situation-bound utterances in L1 and L2. Berlin, Germany/New York, NY: Mouton de Gruyter. 
Kecskes, I. (2008). Dueling contexts: A dynamic model of meaning. Journal of Pragmatics, 40(3), 385-406. https://doi.org/10.1016/j.pragma.2007.12.004

Kecskes, I. (2013). Intercultural pragmatics. Oxford, UK: Oxford University Press.

Kecskes, I., \& Zhang, F. (2009). Activating, seeking, and creating common ground: A sociocognitive approach. Pragmatics \& Cognition, 17(2), 331-355. https://doi.org/10.1075/ pc.17.2.06kec

Kecskes, I., \& Zhang, F. (2013). On the dynamic relations between common ground and presupposition. In A. Capone, F. Lo Piparo, \& M. Carapezza (Eds.), Perspectives on linguistic pragmatics, perspectives in pragmatics, philosophy \& psychology (Vol. 2, pp. 375-395). Cham, Switzerland: Springer.

Keltner, D., \& Lerner, J. (2010). Emotion. In S. Fiske, D. Gilbert, \& G. Lindzey (Eds.), Handbook of social psychology (pp. 317-352). New York, NY: Wiley.

Kerbrat-Orecchioni, C. (1977). La connotation. Lyon, France: Presses Universitaires de Lyon.

Kovecses, Z. (2015). Where metaphors come from: Reconsidering context in metaphor. Oxford, UK: Oxford University Press.

Leech, G. (1981). Semantics: The study of meaning (2nd ed.). Harmondsworth, UK: Penguin.

Leech, G. (1983). Principles of pragmatics. London, UK: Longman.

Loewenstein, G., \& Lerner, J. (2003). The role of affect in decision making. In R. Davidson, K. Scherer, \& H. Goldsmith (Eds.), Handbook of affective science (pp. 619-642). Oxford, UK: Oxford University Press.

Macagno, F. (2012a). Presumptive reasoning in interpretation. Implicatures and conflicts of presumptions. Argumentation, 26(2), 233-265. https://doi.org/10.1007/s10503-011-9232-9

Macagno, F. (2012b). Reconstructing and assessing the conditions of meaningfulness: An argumentative approach to presupposition. In H. Ribeiro (Ed.), Inside arguments: Logic and the study of argumentation (pp. 247-268). Newcastle upon Tyne, UK: Cambridge Scholars Publishing.

Macagno, F. (2015). Presupposition as argumentative reasoning. In A. Capone \& J. Mey (Eds.), Interdisciplinary studies in pragmatics, culture and society (pp. 465-487). Cham, Switzerland: Springer.

Macagno, F. (2017). Defaults and inferences in interpretation. Journal of Pragmatics, 117, 280-290. https://doi.org/10.1016/j.pragma.2017.06.005

Macagno, F., \& Walton, D. (2008). Persuasive definitions: Values, meanings and implicit disagreements. Informal Logic, 28(3), 203-228. https://doi.org/10.22329/il.v28i3.594.

Macagno, F., \& Walton, D. (2010). What we hide in words: Emotive words and persuasive definitions. Journal of Pragmatics, 42(7), 1997-2013. https://doi.org/10.1016/j.pragma.2009.12.003

Macagno, F., \& Walton, D. (2013). Implicatures as forms of argument. In A. Capone, F. Lo Piparo, \& M. Carapezza (Eds.), Perspectives on pragmatics and philosophy (pp. 203-225). Cham, Switzerland: Springer.

Macagno, F., \& Walton, D. (2014). Emotive language in argumentation. Cambridge, UK: Cambridge University Press.

Macagno, F., Walton, D., \& Tindale, C. (2014). Analogical reasoning and semantic rules of inference. Revue Internationale de Philosophie, 270(4), 419-432. https://doi.org/10.3917/ rip. 270.0419 .

Mey, J. (2006). Pragmatic acts. In K. Brown (Ed.), Encyclopedia of language and linguistics (pp. 5-11). Oxford, UK: Elsevier.

Molino, J. (1971). La connotation. La Linguistique, 7(1), 5-30.

Nunberg, G. (2017). The social life of slurs. In D. Fogal, D. Harris, \& M. Moss (Eds.), New work on speech acts. Oxford, UK: Oxford University Press.

Patterson, D. (2005). Interpretation in law. San Diego Law Review, 42, 685-710.

Perelman, C., \& Olbrechts-Tyteca, L. (1951). Act and person in argument. Ethics, 61(4), 251-269.

Petty, R., \& Cacioppo, J. (1986). The elaboration likelihood model of persuasion. Advances in Experimental Social Psychology, 19, 123-205.https://doi.org/10.1016/S0065-2601(08)60214-2

Richard, M. (2008). When truth gives out. Oxford, UK: Oxford University Press. 
Richard, M. (2012). Precis of when truth gives out. Philosophical Studies, 160(3), 441-444. https://doi.org/10.1007/s11098-011-9792-4

Ritchie, D. (2006). Context and connection in metaphor. New York, NY: Palgrave.

Rossi, M. G. (2012). On the nature of moral conflicts. In P. Graziani, L. Guzzardi, \& M. Sangoi (Eds.), Open problems in the philosophy of sciences (pp. 147-159). London, UK: College Publications.

Samet, J., \& Schank, R. (1984). Coherence and connectivity. Linguistics and Philosophy, 7(1), 57-82. https://doi.org/10.1007/BF00627475.

Schlenker, P. (2007). Expressive presuppositions. Theoretical Linguistics, 33(2), 237-245. https:// doi.org/10.1515/TL.2007.017.

Sniderman, P. M., \& Theriault, S. M. (2004). The structure of political argument and the logic of issue framing. In W. Saris \& P. Sniderman (Eds.), Studies in public opinion: Attitudes, nonattitudes, measurement error, and change (pp. 133-165). Princeton, NJ: Princeton University Press.

Sperber, D., \& Wilson, D. (2002). Pragmatics, modularity and mind-reading. Mind and language, 17(1\&2), 3-23. https://doi.org/10.1111/1468-0017.00186

Stevenson, C. (1937). The emotive meaning of ethical terms. Mind, XLVI(181), 14-31. https://doi. org/10.1093/mind/XLVI.181.14

Stevenson, C. (1938a). Ethical judgments and avoidability. Mind, XLVII(185), 45-57. https://doi. org/10.1093/mind/XLVII.185.45

Stevenson, C. (1938b). Persuasive definitions. Mind, 47, 331-350. https://doi.org/10.1093/mind/ xlvii.187.331.

Stevenson, C. (1944). Ethics and language. New Haven, CT: Yale University Press.

Stump, E. (2004). Boethius's "De topicis differentiis". Ithaca, NY and London, UK: Cornell University Press.

Vendler, Z. (1963). The grammar of goodness. The Philosophical Review, 72(4), 446-465.

von Wright, G. (1963a). Norm and action. London, UK: Routledge \& Kegan Paul.

von Wright, G. (1963b). Practical inference. The Philosophical Review, 72(2), 159-179.

von Wright, G. (1963c). The varieties of goodness. London, UK: Routledge.

von Wright, G. (1972). On so-called practical inference. Acta Sociologica, 15(1), 39-53. https:// doi.org/10.1177/000169937201500104

Walton, D. (1995). Argumentation schemes for presumptive reasoning. Mahwah, NJ: Routledge.

Walton, D. (1999). One-sided arguments: A dialectical analysis of bias. Albany, NY: SUNY Press.

Walton, D., \& Krabbe, E. (1995). Commitment in dialogue. Albany, NY: State University of New York Press.

Walton, D., Reed, C., \& Macagno, F. (2008). Argumentation Schemes. New York, NY: Cambridge University Press.

Wheatley, T., \& Haidt, J. (2005). Hypnotic disgust makes moral judgments more severe. Psychological Science, 16(10), 780-784. https://doi.org/10.1111/j.1467-9280.2005.01614.x.

Whiting, D. (2013). It's not what you said, it's the way you said it: Slurs and conventional implicatures. Analytic Philosophy, 54(3), 364-377. https://doi.org/10.1111/phib.12024.

Williamson, T. (2009). Reference, inference and the semantics of pejoratives. In J. Almog \& P. Leonardi (Eds.), The philosophy of David Kaplan (pp. 137-158). Oxford, UK: Oxford University Press. 